\section{Low ozone concentrations promote adipogenesis in human adipose-derived adult stem cells}

\author{
Manuela Costanzo, ${ }^{1}$ Federico Boschi, ${ }^{2}$ \\ Flavia Carton, ${ }^{1}$ Giamaica Conti, ${ }^{1}$ \\ Viviana Covi, ${ }^{3}$ Gabriele Tabaracci, ${ }^{3}$ \\ Andrea Sbarbati, ${ }^{1}$ Manuela Malatesta ${ }^{1}$ \\ ${ }^{1}$ Department of Neurosciences, \\ Biomedicine and Movement Sciences, \\ University of Verona \\ ${ }^{2}$ Department of Computer Science, \\ University of Verona \\ ${ }^{3}$ San Rocco Clinic, Montichiari (BS), \\ Italy
}

\begin{abstract}
Ozone is a strong oxidant, highly unstable atmospheric gas. Its medical use at low concentrations has been progressively increasing as an alternative/adjuvant treatment for several diseases. In this study, we investigated the effects of mild ozonisation on human adipose-derived adult stem (hADAS) cells i.e., mesenchymal stem cells occurring in the stromal-vascular fraction of the fat tissue and involved in the tissue regeneration processes. hADAS cells were induced to differentiate into the adipoblastic lineage, and the effect of low ozone concentrations on the adipogenic process was studied by combining histochemical, morphometric and ultrastructural analyses. Our results demonstrate that ozone treatment promotes lipid accumulation in hADAS cells without inducing deleterious effects, thus paving the way to future studies aimed at elucidating the effect of mild ozonisation on adipose tissue for tissue regeneration and engineering.
\end{abstract}

\section{Introduction}

Ozone $\left(\mathrm{O}_{3}\right)$ is a naturally occurring atmospheric gas composed of three oxygen atoms; it is highly unstable (rapidly decomposing to normal oxygen, $\mathrm{O}_{2}$ ) and is a strong oxidant.

The therapeutic potential of $\mathrm{O}_{3}$ is known since the end of the $18^{\text {th }}$ century but its medical application has been limited for a long time due to the doubts about its possible toxicity. However, in the last two decades the medical use of $\mathrm{O}_{3}$ has been progressively increasing all over the world as an alternative/adjuvant treatment for several diseases. ${ }^{1-3}$ Some mechanistic evidence has recently been provided for the dose-depen- dent effects of $\mathrm{O}_{3}$ treatment. ${ }^{4-6}$ In particular, it has been demonstrated that low $\mathrm{O}_{3}$ concentrations, by inducing the so-called eustress, ${ }^{7}$ do activate cell anti-oxidative response pathways ${ }^{8}$ which are likely responsible for the therapeutic effects observed in the clinical practice.

However, the potential of mild ozonisation in tissue regeneration and differentiation has been scarcely explored so far. In this view, we investigated the effects of low $\mathrm{O}_{3}$ concentrations on human adiposederived adult stem (hADAS) cells i.e., the mesenchymal stem cells which are present in the stromal-vascular fraction of the fat tissue. hADAS cells are able to differentiate in vitro into meso-, ecto- and endodermal cell lineages and can also be reprogrammed as pluripotent stem cells more efficiently than other cell types. ${ }^{9}$ hADAS cells are therefore considered as a powerful tool in regenerative medicine and tissue engineering. ${ }^{9-13}$ In this study, we induced hADAS cells to differentiate into the adipoblastic lineage, and investigated the effect of mild ozonisation on the adipogenic process; histochemical and morphometric analyses at light microscopy were combined with ultrastructural morphology at transmission electron microscopy (TEM).

\section{Materials and Methods}

Technical details of cell culture, gas treatment, cell processing for light microscopy and TEM, and morphometric analysis are reported in the Supplementary Material.

Briefly, hADAS cells were isolated from subcutaneous adipose tissue harvested by liposuction and grown in either adipogenic or non adipogenic medium. These cells were exposed to 5,10 or $20 \mu \mathrm{g} \mathrm{O}_{3} / \mathrm{mL}$ $\mathrm{O}_{2}$ at early (6 days), intermediate (16 days) and late (20 days) differentiation steps, and the effects were evaluated $2 \mathrm{~h}$ and $24 \mathrm{~h}$ after gas exposure.

After 6 days in differentiation medium, cell viability was estimated by the Trypanblue exclusion test $2 \mathrm{~h}$ and $24 \mathrm{~h}$ after gas treatment. Since $20 \mu \mathrm{g} \mathrm{O}_{3} / \mathrm{mL}$ was found to significantly increase cell death (Figure 1), this concentration was excluded from further analyses.

Oil Red O staining was used to visualize lipid droplets (LDs) at light microscopy. Two $\mathrm{h}$ and $24 \mathrm{~h}$ after gas treatment, randomly selected cells grown in either adipogenic or non-adipogenic medium were measured to evaluate the percentage of cytoplasmic area covered by LDs, mean LD areas, and LD size distribution. Twenty-four $h$ after treatment, hADAS cells were processed for conventional TEM.
Correspondence: Manuela Malatesta, Department of Neurosciences, Biomedicine and Movement Sciences, University of Verona, Strada Le Grazie 8, 37134 Verona, Italy.

Tel. +39.045.8027569.

E-mail: manuela.malatesta@univr.it

Key words: Ozone; stem cells; adipogenesis; microscopy.

Acknowledgments: This work was supported by the University of Verona (Joint Projects 2017). F.C. is a PhD student in receipt of a fellowship from the Doctoral Program "Nanoscience and Advanced Technologies" of the University of Verona.

Received for publication: 13 July 2018. Accepted for publication: 20 August 2018.

This work is licensed under a Creative Commons Attribution-NonCommercial 4.0 International License (CC BY-NC 4.0).

CCopyright M. Costanzo et al., 2018

Licensee PAGEPress, Italy

European Journal of Histochemistry 2018; 62:2969 doi:10.4081/ejh.2018.2969

\section{Results and Discussions}

\section{Low $\mathrm{O}_{3}$ concentrations do not affect} hADAS cells viability

Two $h$ after gas exposure, cell death rate significantly raised in samples treated with $\mathrm{O}_{2}$ or $20 \mu \mathrm{g} \mathrm{O} / \mathrm{mL}$ in comparison to the untreated control (Figure 1): this suggests that excessive concentrations of $\mathrm{O}_{3}$ as well as pure $\mathrm{O}_{2}$ induce the formation of high levels of reactive oxygen species (ROS), which cause cell damage by oxidation and nitration of DNA, RNA, protein and lipids. ${ }^{14}$ Conversely, exposure to 5 or $10 \mu \mathrm{g} \mathrm{O}_{3} / \mathrm{mL}$ proved to be safe for hADAS cells at both short and long term post treatment. Regulated ROS levels are known to promote essential signalling pathways involved in cell proliferation, survival and differentiation in mesenchymal stem cells; ${ }^{14}$ it is therefore likely that 5 and $10 \mu \mathrm{g} \mathrm{O}_{3} / \mathrm{mL}$ are safe concentrations for hADAS cells, able to activate positive anti-stress cell response involving e.g. Nrf2, HSP70, mtHSP70, ${ }^{15,16}$ similarly to other cell types submitted to mild ozonisation..$^{5-8}$

\section{Low $\mathrm{O}_{3}$ concentrations induce adi- pogenesis in hADAS cells in adipo- genic medium}

The effects of 5 and $10 \mu \mathrm{g} \mathrm{O}_{3} / \mathrm{mL}$ treatment in hADAS cells grown in adipogenic medium are shown in Figure 2. These results refer to $24 \mathrm{~h}$ post treatment, since no change was observed after $2 \mathrm{~h}$ (not shown). 
At early stage of differentiation (6 days), hADAS cells contained few small LDs (Figure 2a-d), although cells exposed to $10 \mu \mathrm{g} \mathrm{O}_{3} / \mathrm{mL}$ showed more numerous LDs than the other samples (Figure 2d). Morphometric evaluation confirmed that $10 \mu \mathrm{g} \mathrm{O} / \mathrm{mL}$-treated cells showed both mean LD area and lipid percentage values higher than the controls (Figure $2 \mathrm{f}, \mathrm{g}$ ), together with numerous large LDs (Figure $2 \mathrm{e})$. At the intermediate stage of differentiation (16 days), hADAS cells contained numerous LDs (Figure 2 a'-d'). Morphometric evaluation demonstrated a decreased mean LD area in cells treated with $\mathrm{O}_{2}, 5 \mu \mathrm{g} \mathrm{O}_{3} / \mathrm{mL}$ or $10 \mu \mathrm{g} \mathrm{O}_{3} / \mathrm{mL}$ (Figure 2f'); in addition, cells treated with 5 or $10 \mu \mathrm{g} \mathrm{O}_{3} / \mathrm{mL}$ showed an increase in lipid percentage (Figure 2g'). Accordingly, numerous LDs of small size are present in these samples (Figure 2e'). At late differentiation (20 days) stage, hADAS cells contained a large number of LDs in all samples (Figure 2 a"-d"); however, treatment with $10 \mu \mathrm{g} \mathrm{O}_{3} / \mathrm{mL}$ significantly increased both LD area (Figure $2 \mathrm{f}^{\prime \prime}$ ) and lipid percentage (Figure 2g"), consistently with the presence of the highest number of large LDs (Figure $2 \mathrm{e} ")$.

LDs are depot of neutral lipids which represent an energy source as well as a substrate for the synthesis of several molecules. Generally, LD formation occurs by steps: first scattered small droplets form in the cytoplasm, then LDs increase in size and finally aggregate into clusters. ${ }^{17}$ In white adipocytes, increase in LD size may occur by either addition of neutral lipids to preexisting droplets ${ }^{18,19}$ or LDs fusion. ${ }^{20,21}$

An adipogenic effect of mild ozonisation (especially for $10 \mu \mathrm{g} \mathrm{O}_{3} / \mathrm{mL}$ ) on differentiating pre-adipocytes is demonstrated by our data. This effect varies in relation to the differentiation phase: at early and late stages $\mathrm{O}_{3}$ seems to stimulate lipid addition to LDs and/or LD fusion (as suggested by the increased mean area of LDs) whereas at

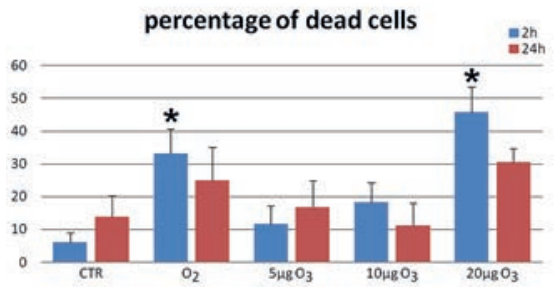

Figure 1. Mean values \pm SE of dead cell percentage in the different samples $2 \mathrm{~h}$ (blue columns) and $24 \mathrm{~h}$ (red columns) after treatment. Asterisks indicate values significantly different from control at the same time point. the intermediate differentiation step $\mathrm{O}_{3}$ would also stimulate the formation of new LDs (as suggested by the significantly decreased mean area). At this stage, LD size was also affected by $\mathrm{O}_{2}$; however, the total lipid content did not increase, thus excluding an $\mathrm{O}_{2}$-induced adipogenic effect. It has been reported that appropriate ROS levels are essential for adipogenic differentiation of mesenchymal stem cells. ${ }^{14,22}$ Moreover, Nrf2 has been demonstrated to play a key role in human mesenchymal stem cell differentiation $^{23,24}$ together with Heme Oxygenase- $1 ; 25$ consistently, mild ozonisation activates an antioxidant cell response through Nrf2 pathway $^{8}$ and Heme Oxygenase-1 modulation. ${ }^{6}$ It is noteworthy that no LD fission or decrease of the cell lipid content ${ }^{26,27}$ was observed even short time post-treatment (not shown): since lipolysis may be caused in adipocytes by different stress conditions, ${ }^{28-30}$ its absence further supports the safety of the low $\mathrm{O}_{3}$ concentrations.

This was also confirmed by the ultrastructural analysis. At 6 days (Figure 3 a-c),
hADAS cells of all samples were characterized by elongated shapes and one nucleus containing scattered heterochromatin clumps; in the cytoplasm mitochondria were numerous, rough and smooth endoplasmic reticulum and Golgi complex were well developed, while LDs and glycogen were quite scarce. At this differentiation step, in cells treated with $10 \mu \mathrm{g} \mathrm{O}_{3} / \mathrm{mL}$ LDs were frequently found to fuse (Figure $3 \mathrm{c}$ ), according to the significant increase of the mean LD size. At both 16 and 20 days (Figure $3 \mathrm{~d}-\mathrm{g}$ ), hADAS cells showed roundish shapes and one mostly euchromatic nucleus; in the cytoplasm mitochondria were numerous, rough and smooth endoplasmic reticulum were well developed, Golgi complexes were numerous with many cisternae and vesicles, LDs and glycogen were abundant, especially in cells treated with $10 \mu \mathrm{g} / \mathrm{mL}$ (Figure 3f). Low $\mathrm{O}_{3}$ concentrations would therefore promote not only lipid but also glycogen accumulation. Taken together, TEM observations revealed that $\mathrm{O}_{3}$ treatment did not hamper the differentiation process of hADAS cell from elongated,
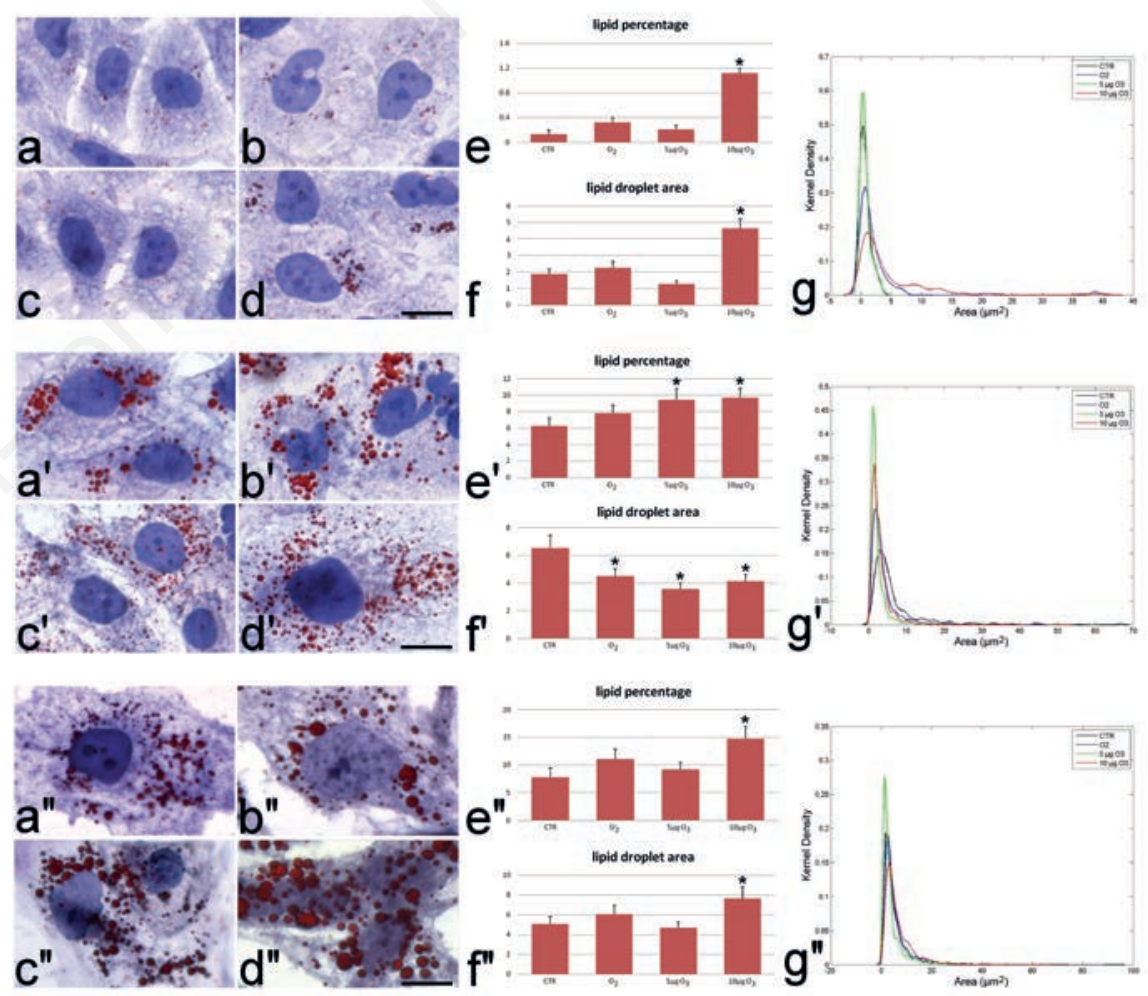

Figure 2. Brightfield micrographs of hADAS cells grown in adipogenic medium. Control (a, a', a"), $\mathrm{O}_{2}$-treated (b, b', b”), $5 \mu \mathrm{g} \mathrm{O}_{3}$-treated (c, c', c") and $10 \mu \mathrm{g} \mathrm{O}_{3}$-treated (d, d', d") hADAS cells at day 6 (a-d), 16 (a'-d') and 20 (a"-d"). LDs were stained with Oil Red O and the cell was counterstained with haematoxylin. Note the progressive accumulation of LDs during the differentiation process. Scale bars: $20 \mu \mathrm{m}$. Mean values \pm SE of percentage of cytoplasmic area covered by LDs (e-e") and of LD area (f-f") at 24 h post-treatment. Asterisks indicate values significantly different from control. Kernel distribution of LD area (g-g"). 
fibroblast-like cells with heterochromatic nuclei (i.e., containing only partially transcribing DNA), to roundish adipocyte-like cells with euchromatic (i.e., actively transcribing) nuclei and large amounts of lipid and glycogen in the cytoplasm. Moreover, no alteration of the cell organelles occurred in samples treated with low $\mathrm{O}_{3}$ concentrations at any differentiation step, according to previous ultrastructural observations on other cell types..$^{5-8}$

Notably, cells treated with $\mathrm{O}_{2}$ showed an evident vacuolization of the cytoplasm and an accumulation of residual bodies at each differentiation step, although no structural damage of cell organelles was observed, suggesting that treatment with pure $\mathrm{O}_{2}$ induces cell stress, consistently with the observed increase in cell death rate (Figure 1).

Low $\mathrm{O}_{3}$ concentrations do not affect adipogenesis in the absence of adipogenic factors

When hADAS cells were grown in medium devoid of adipogenic factors, most of the cells maintained fibroblast-like morphology (not shown), and only a few clones accumulated LDs. Morphometric evaluation of lipid content was therefore performed exclusively in these cells.

Under this culture condition, no effect was observed for any gas treatment both at short (not shown) and long (Figure 4) time. In detail, at 6 days, the cells showed only few small LDs (Figure 4a), with no significant difference in the mean LD area or lipid percentage (Figure 4 b,c), while the Kernel density distribution showed a trend towards larger LD size in $\mathrm{O}_{3}$ treated cells. At 16 and 20 days, some LDs accumulated in the cytoplasm (Figure 4a'), but no significant difference in LD area, lipid percentage or Kernel density among samples was found (Figure 4 b'-d', b"-d"). Interestingly, the amount of lipid content at 20 days was generally lower than at 16 days, demonstrating a hampered pre-adipocyte differentiation in the absence of adipogenic factors. ROS are known to promote adipogenesis via insulin-mediated signal transduction ${ }^{31}$ and it is likely that the absence of insulin in the medium may prevent the adipogenic effect of low $\mathrm{O}_{3}$ concentrations.

In conclusion, our results demonstrate that low $\mathrm{O}_{3}$ concentrations are able to stimulate lipid accumulation during adipogenic differentiation of hADAS cells without altering cell differentiation process, ultrastructural cytoarchitecture or lipid storage. In particular, lipids play a key role as signaling factors in the regulation of metabolism as well as in cell response (protection and reparation) to damaging stimuli, thus representing a powerful marker of cell func-
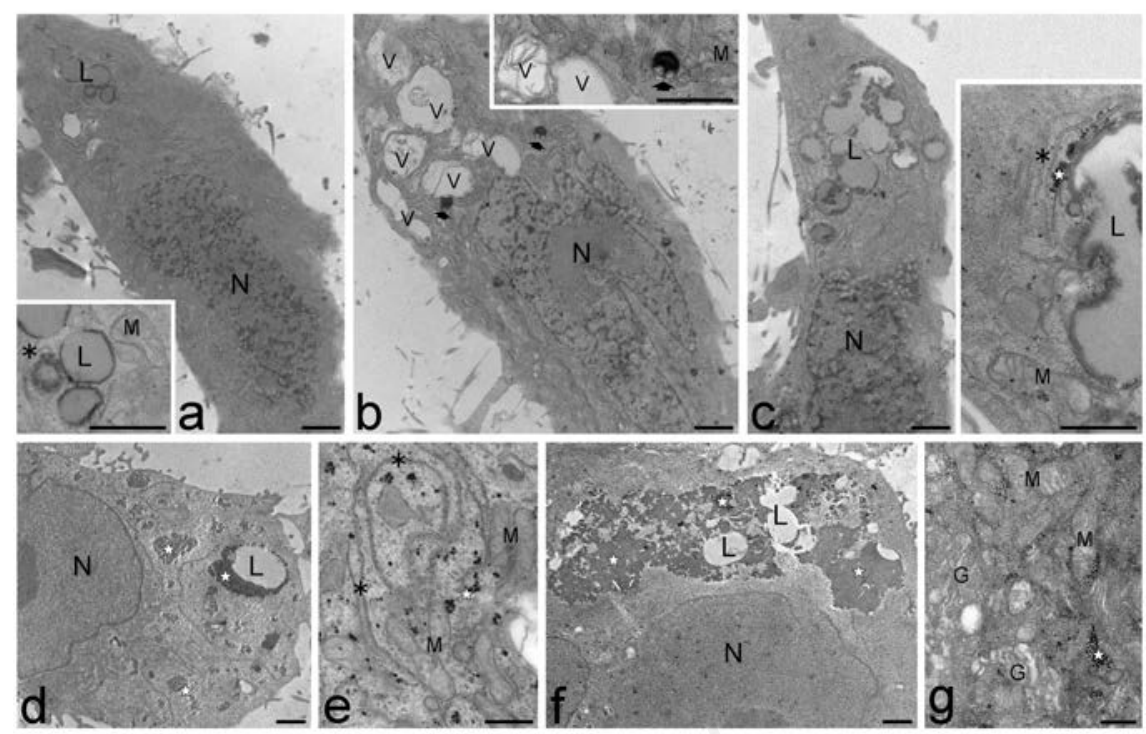

Figure 3. Transmission electron micrographs of hADAS cells. a-c) Control (a), $\mathrm{O}_{2}$ treated (b) and $\mathrm{O}_{3} 10 \mu \mathrm{g} / \mathrm{mL}$ treated (c) cells at early differentiation stage (6 days). The cells are elongated in shape and show nuclei $(N)$ with numerous heterochromatin clumps; in the cytoplasm mitochondria $(\mathrm{M})$ and endoplasmic reticulum (asterisks) are well developed, even after gas exposure while glycogen (star) is scarce. Note the cytoplasmic vacuolization (V) and the residual bodies (arrows) in b, and the merging LDs (L) in c. d-g) Control $(\mathrm{d}, \mathrm{e})$, and $\mathrm{O}_{3} 10 \mu \mathrm{g} / \mathrm{mL}$ treated $(\mathrm{f}, \mathrm{g})$ cells at late differentiation stage (20 days). The roundish cells contain one mostly euchromatic nucleus $(\mathrm{N})$ and numerous mitochondria (M) and Golgi complexes (G); LDs (L) and glycogen (stars) are abundantly distributed in the cytoplasm. Note the large amount of glycogen in $\mathrm{f}$. Scale bars: a-d, f) $2 \mu \mathrm{m} ; \mathrm{e}, \mathrm{g}$ ) $500 \mathrm{~nm}$.
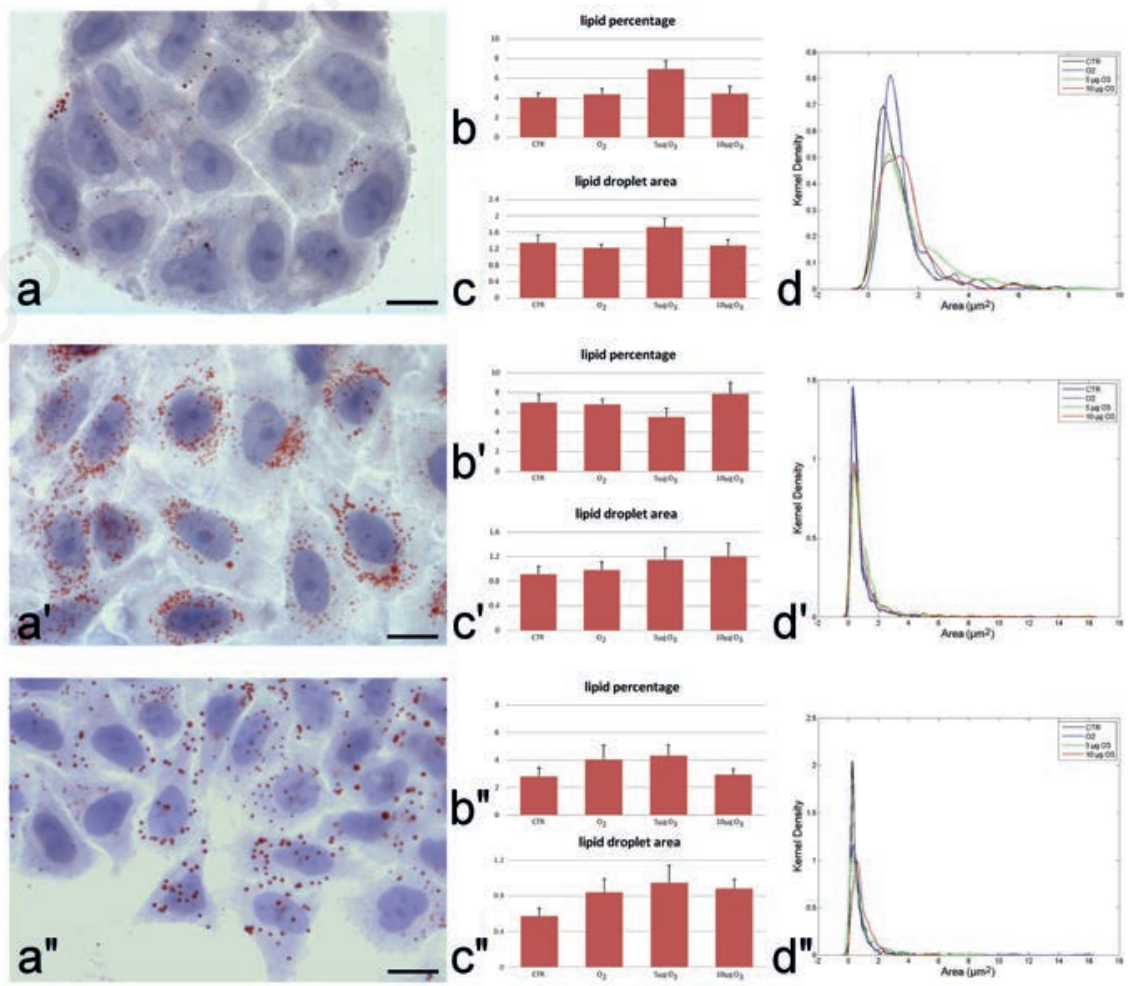

Figure 4. Representative brightfield micrographs of hADAS cells grown in DMEM at day 6 (a), 16 (a') and 20 (a"). LDs were stained with Oil Red $O$ and the cell was counterstained with haematoxylin. Note the increase of LDs at day 16 (a') and the decrease at day 20. Scale bars: $20 \mu \mathrm{m}$. Mean values $\pm S E$ of percentage of cytoplasmic area occupied by $L D s$ (b-b") and of LD area (c-c") at 24 h post-treatment. No significant difference was found. Kernel distribution of LD area (d-d"). 
tion. ${ }^{32-34}$ hADAS cells are a suitable in vitro model to explore the effect of mild ozonisation on the regeneration processes since these stem cells are involved in reconstructing the connective matrix and promoting angiogenesis, while supporting epithelial, muscle and even nerve regeneration in vivo. ${ }^{9}$ Based on the present preliminary findings, future studies in vitro and in vivo will elucidate the effect of mild ozonisation on human adipose tissue, in the attempt to design targeted protocols of ozone treatment for adipose stem cell-based tissue regeneration and engineering.

\section{References}

1. Re L, Mawsouf MN, Menéndez S, León OS, Sánchez GM, Hernández F. Ozone therapy: clinical and basic evidence of its therapeutic potential. Arch Med Res 2008;39:17-26.

2. Elvis AM, Ekta JS. Ozone therapy: A clinical review. J Nat Sc Biol Med 2011;2:66-70.

3. Bocci V. How a calculated oxidative stress can yield multiple therapeutic effects. Free Radic Res 2012;46:106875.

4. Sagai M, Bocci V. Mechanisms of action involved in ozone therapy: is healing induced via a mild oxidative stress? Med Gas Res 2011;1:29.

5. Costanzo M, Cisterna B, Vella A, Cestari T, Covi V, Tabaracci G, et al. Low ozone concentrations stimulate cytoskeletal organization, mitochondrial activity and nuclear transcription. Eur J Histochem 2015;59:2515.

6. Scassellati C, Costanzo M, Cisterna B, Nodari A, Galiè M, Cattaneo A, et al. Effects of mild ozonisation on gene expression and nuclear domains organization in vitro. Toxicol in Vitro 2017;44:100-10.

7. Niki E. Oxidative stress and antioxidants: Distress or eustress? Arch Biochem Biophys 2016; 595:19-24.

8. Galiè M, Costanzo M, Nodari A, Boschi F, Calderan L, Mannucci S, et al. Mild ozonisation activates antioxidant cell response by the Keap1/Nrf2 dependent pathway. Free Radic Biol Med 2018; 124:114-21.

9. Ong WK, Sugii S. Adipose-derived stem cells: fatty potentials for therapy. Int $\mathrm{J}$ Biochem Cell Biol 2013;45:1083-6.

10. Rigotti G, Marchi A, Galiè M, Baroni G, Benati D, Krampera $M$, et al. Clinical treatment of radiotherapy tissue damage by lipoaspirate transplant: a healing process mediated by adiposederived adult stem cells. Plast Reconstr
Surg 2007;119:1409-22.

11. Rigotti G, Marchi A, Sbarbati A. Adipose-derived mesenchymal stem cells: past, present, and future. Aesthetic Plast Surg 2009;33:271-3.

12. Salibian AA, Widgerow AD, Abrouk M, Evans GR. Stem cells in plastic surgery: a review of current clinical and translational applications. Arch Plast Surg 2013;40:666-75.

13. Tsuji W, Rubin JP, Marra KG. Adiposederived stem cells: Implications in tissue regeneration. World J Stem Cells 2014;6:312-21.

14. Atashi F, Modarressi A, Pepper MS. The role of reactive oxygen species in mesenchymal stem cell adipogenic and osteogenic differentiation: a review. Stem Cells Dev 2015;24:1150-63.

15. Wadhwa R, Taira K, Kaul SC. An Hsp70 family chaperone, mortalin/ mthsp70/PBP74/Grp75: what, when, and where? Cell Stress Chaperones 2002;7:309-16.

16. Flachbartová Z, Kovacech B. Mortalin a multipotent chaperone regulating cellular processes ranging from viral infection to neurodegeneration. Acta Virol 2013;57:3-15.

17. Guo Y, Walther TC, Rao M, Stuurman N, Goshima G, Terayama K, et al. Functional genomic screen reveals genes involved in lipid droplet formation and utilization. Nature 2008;453:657-61.

18. Kellner-Weibel G, McHendry-Rinde B, Haynes MP, Adelman S. Evidence that newly synthesized esterified cholesterol is deposited in existing cytoplasmic lipid inclusions. J Lipid Res 2001;42: 768-77.

19. Kuerschner L, Moessinger C, Thiele C. Imaging of lipid biosynthesis: how a neutral lipid enters lipid droplets. Traffic 2008;9:338-52.

20. Boström P, Rutberg M, Ericsson J, Holmdahl P, Andersson L, Frohman MA, et al. Cytosolic lipid droplets increase in size by microtubule-dependent complex formation. Arterioscler Thromb Vasc Biol 2005;25:1945-51.

21. Murphy S, Martin S, Parton RG. Lipid droplet-organelle interactions; sharing the fats. Biochim Biophys Acta 2009; 1791:441-7.

22. Higuchi M, Dusting GJ, Peshavariya H, Jiang F, Hsiao ST, Chan EC, et al. Differentiation of human adiposederived stem cells into fat involves reactive oxygen species and Forkhead box $\mathrm{O} 1$ mediated upregulation of antioxidant enzymes. Stem Cells Dev 2013;22:878-88.

23. Pi J, Leung L, Xue P, Wang W, Hou Y,
Liu D, et al. Deficiency in the nuclear factor E2-related factor-2 transcription factor results in impaired adipogenesis and protects against diet-induced obesity. J Biol Chem 2010;285(12):9292300.

24. Hou Y, Xue P, Bai Y, Liu D, Woods CG, Yarborough K, et al. Nuclear factor erythroid-derived factor 2-related factor 2 regulates transcription of CCAAT /enhancer-binding protein $\beta$ during adipogenesis. Free Radic Biol Med 2012;52:462-72.

25. Vanella L, Sanford C Jr, Kim DH, Abraham NG, Ebraheim N. Oxidative stress and heme oxygenase-1 regulated human mesenchymal stem cells differentiation. Int J Hypertens 2012;2012: 890671.

26. Rizzatti V, Boschi F, Pedrotti M, Zoico E, Sbarbati A, Zamboni M. Lipid droplets characterization in adipocyte differentiated 3T3-L1 cells: size and optical density distribution. Eur J Histochem 2013;57:e24.

27. Boschi F, Rizzatti V, Zamboni M, Sbarbati A. Models of lipid droplets growth and fission in adipocyte cells. Exp Cell Res 2015;336:253-62.

28. Deng J, Liu S, Zou L, Xu C, Geng B, $\mathrm{Xu}$ G. Lipolysis response to endoplasmic reticulum stress in adipose cells. J Biol Chem 2012;287:6240-9.

29. Conti G, Benati D, Bernardi P, Jurga M, Rigotti G, Sbarbati A. The postadipocytic phase of the adipose cell cycle. Tissue Cell 2014;46:520-6.

30. Marinozzi MR, Pandolfi L, Malatesta M, Colombo M, Collico V, Lievens PM, et al. Innovative approach to safely induce controlled lipolysis by superparamagnetic iron oxide nanoparticlesmediated hyperthermic treatment. Int $\mathrm{J}$ Biochem Cell Biol 2017;93:62-73.

31. Zhang Z, Zhou S, Jiang X, Wang YH, Li F, Wang YG, et al. The role of the Nrf2/Keap1 pathway in obesity and metabolic syndrome. Rev Endocr Metab Disord 2015;16:35-45.

32. Wymann MP, Schneiter R. Lipid signalling in disease. Nat Rev Mol Cell Biol 2008;9:162-76.

33. Carroll B, Donaldson JC, Obeid L. Sphingolipids in the DNA damage response. Adv Biol Regul 2015;58:3852.

34. Croce AC, Bottiroli G. Lipids: Evergreen autofluorescent biomarkers for the liver functional profiling. Eur J Histochem 2017;61:2808. 